\title{
INTERNATIONAL ASSOCIATION OF
}

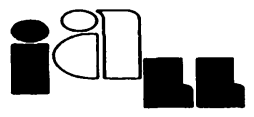

\section{LAW LIBRARIES}

\section{MEMBERSHIP APPLICATION}

International Association of Law Libraries

P.O. Box 5709

Washington, D.C. 20016-1309

U.S.A.

Name of Applicant

Name of Institution

Address

Phone

Fax

E-mail

Please check one: Personal Membership (\$60)

Institutional Membership (\$95)

Sustaining Membership (\$250)

Make check payable to the International Association of Law Libraries and send it with the application to the above address. 


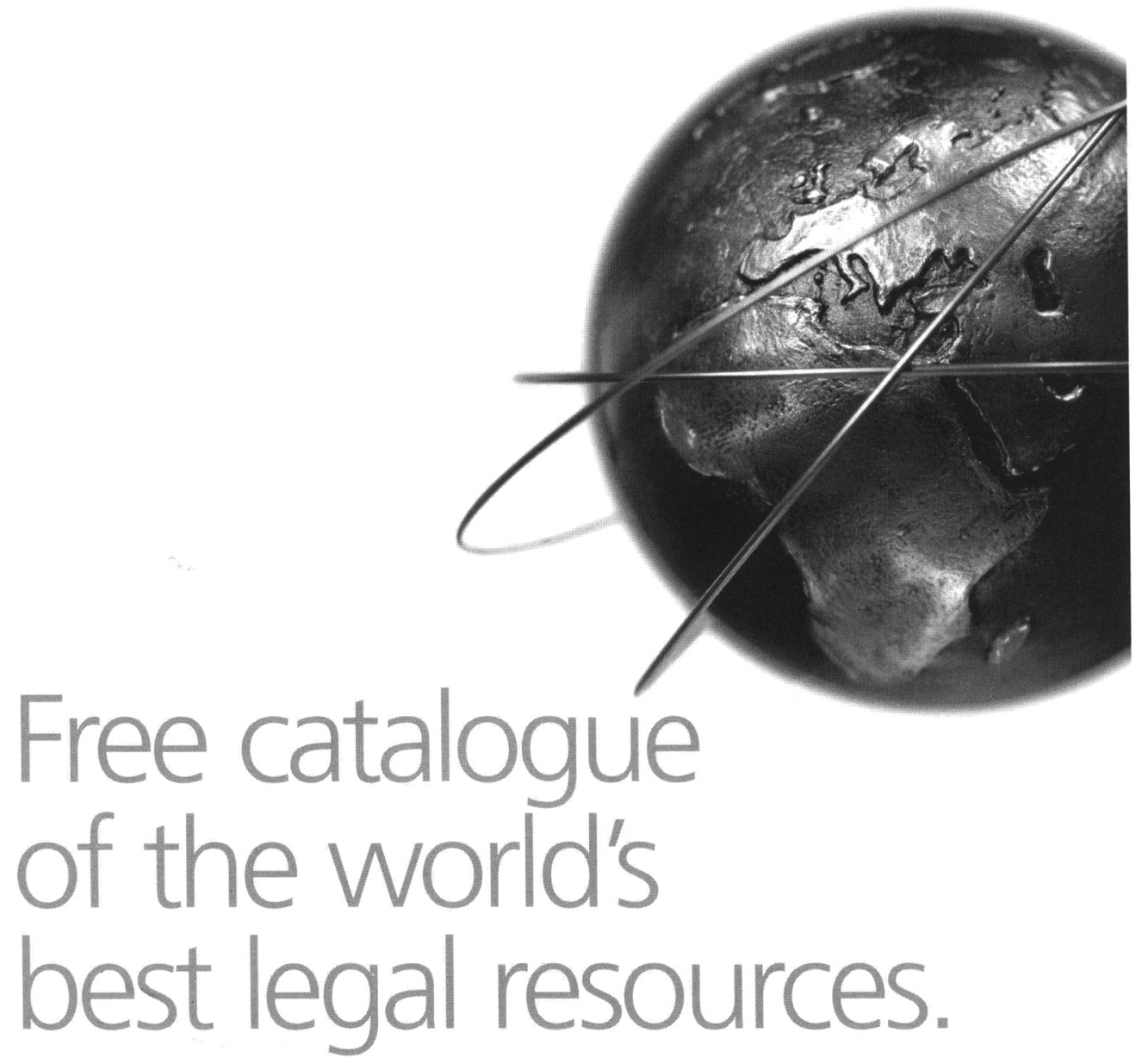

Finding legal information from around the world has gotten easier.

Thomson International Catalogue lets you choose from hundreds of books, journals, CD-ROMs, and online resources from the world's best publishers.

In it you'll find legal, regulatory, tax, and accounting offerings from 24 publishers.

Best of all, one phone call allows you to talk to an expert who can guide your selection, then get it into your office quickly, easily, and efficiently.

\section{fReE CATALOGUe}

To request your free Thomson International Catalogue with information from around the world, please send an e-mail to the person nearest you.

\section{Asia Pacific}

vivienne.goodman@thomson.com.au

\section{Americas}

international@carswell.com

\section{Europe, Middle East \& Africa}

international@t|reurope.com

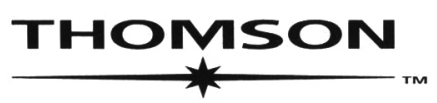


INTERNATIONAL JOURNAL

OF LEGAL INFORMATION

P.O. Box 5709

Washington, DC 20016-1309

U.S.A.

(202) 707-9866

Fax: (202) 707-1820

E-mail: mber@loc.gov

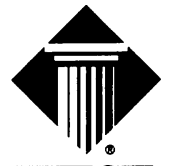

WEST

GROUP

A THOMSON COMPANY 